\title{
Inheritance of Resistance to Common Bacterial Blight in Four Tepary Bean Lines
}

\author{
Carlos A. Urrea ${ }^{1}$ \\ Department of Agronomy and Soils, University of Puerto Rico, Mayagüez, PR 00681 \\ Phillip N. Miklas ${ }^{2}$ \\ U.S. Department of Agriculture, Agriculture Research Service, Irrigated Agriculture Research and \\ Extension Center, 24106 North Bunn Road, Prosser, WA 99350
}

\author{
James S. Beaver \\ Department of Agronomy and Soils, University of Puerto Rico, Mayagüez, PR 00681
}

\begin{abstract}
AdDitional INDEX words. Phaseolus acutifolius, Xanthomonas campestris pv. phaseoli
Abstract. High levels of resistance to common bacterial blight caused by Xanthomonas campestris pv. phaseoli (Smith) Dye (Xcp) have been observed for tepary bean (Phaseolus acutifolius A. Gray var. latifolius Freeman). However, the inheritance of resistance from this source is unknown for many lines. The inheritance of common bacterial blight resistance was studied in four tepary bean lines crossed with the susceptible tepary bean MEX-114. Progenies were inoculated with a single $X c p$ strain 484a. Segregation ratios in the $F_{2}$ generation suggested that resistance in Neb-T-6-s and PI 321637-s was governed by one dominant gene, and Neb T-8a-s had two dominant genes with complementary effects. These hypotheses for inheritance of resistance were supported by various combinations of $F_{1}, F_{3}, B_{1} P_{n}$ segregation data in all lines except PI 321637-s where an additional minor-effect gene with recessive inheritance was indicated. Generation means analyses corroborated that multiple resistance genes were present in PI 321638-s. Lack of segregation for susceptibility among testcrosses for allelism between Neb-T-6-s/PI 321637-s, Neb-T-6-s/Neb-T-8a-s, PI 321637-s/Neb-T8a-s, and PI 321637-s/PI 321638-s, suggested that one or more loci conditioning resistance to common bacterial blight were in common across the four tepary lines.
\end{abstract}

The value of tepary bean as a potential gene donor of resistance to common bacterial blight and other useful traits to common bean (Phaseolus vulgaris L.) via interspecific hybridization has been noted (Mejía-Jiménez et al., 1994; Pratt and Gordon, 1994). For common bacterial blight resistance introgressed from tepary to common bean, both quantitative (Honma, 1956) and qualitative (Michaels, 1992) patterns of inheritance were observed. Mixed inheritance was corroborated by genetic marker analyses revealing that the tepary-derived resistance was conditioned by multiple loci, and with one locus usually exhibiting a prominent effect (Bai et al., 1997; Jung et al., 1997; Miklas et al., 1996; Nodari et al., 1993).

The genetics of resistance to common bacterial blight within tepary bean itself has been investigated by several researchers. Drijfhout and Blok (1987) observed that the resistance in PI 319443 was governed by one dominant gene. Conversely, McElroy (1985) working with PI 319443 and Scott (1988) working with PI 440795 both found three genes conditioned resistance with one having a major effect and two having modifying effects. A series of tightly linked genes were observed when multiple $X c p$ strains were included in the genetic analysis of tepary bean resistance to common bacterial blight (Cafati and Kimati, 1972; Dursun et al., 1995; Freytag, 1989). Park et al. (1998) found molecular markers tightly linked to three genes, one for resistance to each of three

Received for publication 24 Feb. 1998. Accepted for publication 16 Sept. 1998. We acknowledge J. Santiago for technical assistance and M. Zapata for Xcp strain 484a. Use of a company name or product by the USDA does not imply approval or recommendation of the product to the exclusion of others that also may be suitable. The cost of publishing this paper was defrayed in part by the payment of page charges. Under postal regulations, this paper therefore must be hereby marked advertisement solely to indicate this fact.

${ }^{1}$ Current address: Dept. of Plant Sciences, North Dakota State University, Fargo, ND 58105.

${ }^{2}$ To whom reprint requests should be addressed. different $X c p$ strains in a tepary cross. Generally, each combination of a linked gene conditioning resistance to a specific strain segregated 3:1 as expected for a dominant gene in the $F_{2}$ generation.

Our objective was to study the inheritance of resistance in other tepary bean lines identified by Miklas et al. (1994) as having high levels of field resistance to common bacterial blight. Information gained should facilitate continued introgression of common bacterial blight resistance from tepary to the highly susceptible common bean.

\section{Materials and Methods}

Four cultivated tepary bean lines: Neb-T-6-s $\left(\mathrm{P}_{1}\right)$, Neb-T-8a-s $\left(\mathrm{P}_{2}\right)$, PI 321637-s $\left(\mathrm{P}_{3}\right)$, and PI 321638-s $\left(\mathrm{P}_{4}\right)$, expressing high levels of field resistance to common bacterial blight in Puerto Rico (Miklas et al., 1994) were crossed to the susceptible tepary bean MEX-114 ( $\left.\mathrm{P}_{5}\right)$ (Freytag, 1989). The Neb-lines originated from a University of Nebraska tepary bean collection likely obtained from Freeman (S. Honma, personal communication, 1993), and the PIs were collected in Arizona. All four resistant lines represent selections (-s) from the original sources for uniform disease reaction, seed type, and growth habit (Miklas et al., 1994). Seeds of these lines may be requested from P.N. Miklas. For most crosses, disease reactions of individuals within $\mathrm{F}_{1}, \mathrm{~F}_{2}, \mathrm{BC}_{1} \mathrm{P}_{\mathrm{n}}$, and $\mathrm{F}_{3}$, progenies were examined. Only the $\mathrm{F}_{2}$ and $\mathrm{F}_{3}$ generations were evaluated from the cross involving PI 321637-s. Allelism among potentially different sources of resistance were tested in $\mathrm{F}_{2}$ progenies generated from crosses among resistant lines: Neb-T-6-s/PI 321637-s, Neb-T-6-s/Neb-T-8a-s, PI 321637-s/Neb-T-8a-s, and PI 321637-s/PI 321638-s.

All parents and progenies were inoculated by a single strain of the pathogen, Xcp 484a (courtesy of M. Zapata, University of Puerto Rico, Mayagüez, PR) that was isolated from dry bean growing in Juana Díaz, Puerto Rico. Plants were grown under 
Table 1. Average disease score for the parents and $\mathrm{F}_{1}$ progeny and distribution of individual $\mathrm{F}_{2}$ and backcross plants for reaction to common bacterial blight in four populations derived from resistant $\mathrm{X}$ susceptible tepary bean $\left(\mathrm{F}_{2}\right.$ distributions for four crosses between resistant tepary bean are also included $)$.

\begin{tabular}{|c|c|c|c|c|c|c|c|c|c|c|c|c|c|}
\hline \multirow[b]{2}{*}{ Population } & \multicolumn{3}{|c|}{$\begin{array}{l}\text { Mean score } \\
(1-9)^{z}\end{array}$} & \multicolumn{10}{|c|}{$\begin{array}{l}\text { Distribution for disease score } \\
\text { (no. of plants) }\end{array}$} \\
\hline & $P_{1-4}$ & $\mathrm{P}_{5}$ & $\mathrm{~F}_{1}$ & Generation & 1 & 2 & 3 & 4 & 5 & 6 & 7 & 8 & 9 \\
\hline \multicolumn{14}{|l|}{ Resistant X susceptible } \\
\hline \multirow[t]{3}{*}{ Neb-T-6-s $\left(\mathrm{P}_{1}\right) / \mathrm{MEX}-114\left(\mathrm{P}_{5}\right)$} & 1.1 & 9.0 & 2.0 & $\mathrm{~F}_{2}$ & 91 & 82 & 26 & 23 & 19 & 6 & 16 & 17 & 19 \\
\hline & & & & $\mathrm{BC}_{1} \mathrm{P}_{1}$ & 6 & 12 & 2 & 1 & 0 & 0 & 0 & 1 & 3 \\
\hline & & & & $\mathrm{BC}_{1} \mathrm{P}_{5}$ & 0 & 0 & 1 & 2 & 0 & 0 & 2 & 1 & 3 \\
\hline PI 321637-s $\left(\mathrm{P}_{2}\right) / \mathrm{MEX}-114\left(\mathrm{P}_{5}\right)$ & 1.8 & 9.0 & --- & $\mathrm{F}_{2}$ & 24 & 26 & 24 & 5 & 4 & 2 & 7 & 4 & 10 \\
\hline \multirow[t]{3}{*}{ Neb-T-8a-s $\left(\mathrm{P}_{3}\right) / \mathrm{MEX}-114\left(\mathrm{P}_{5}\right)$} & 1.1 & 9.0 & 1.0 & $\mathrm{~F}_{2}$ & 17 & 36 & 33 & 14 & 10 & 7 & 19 & 8 & 19 \\
\hline & & & & $\mathrm{BC}_{1} \mathrm{P}_{3}$ & 5 & 13 & 11 & 6 & 2 & 0 & 0 & 0 & 1 \\
\hline & & & & $\mathrm{BC}_{1} \mathrm{P}_{5}$ & 1 & 0 & 3 & 2 & 0 & 0 & 1 & 0 & 33 \\
\hline \multirow[t]{3}{*}{ PI 321638-s $\left(\mathrm{P}_{4}\right) / \mathrm{MEX}-114\left(\mathrm{P}_{5}\right)$} & 1.0 & 9.0 & 1.6 & $\mathrm{~F}_{2}$ & 94 & 44 & 23 & 7 & 10 & 2 & 5 & 0 & 2 \\
\hline & & & & $\mathrm{BC}_{1} \mathrm{P}_{4}$ & 12 & 3 & 0 & 0 & 0 & 0 & 0 & 0 & 0 \\
\hline & & & & $\mathrm{BC}_{1} \mathrm{P}_{5}$ & 1 & 2 & 5 & 5 & 1 & 0 & 1 & 0 & 14 \\
\hline \multicolumn{14}{|l|}{ Resistant $\mathrm{x}$ resistant } \\
\hline Neb-T-6-s/PI 321637-s & & & & $\mathrm{F}_{2}$ & 79 & 1 & 1 & 0 & 0 & 0 & 0 & 0 & 0 \\
\hline Neb-T-6-s/Neb-T-8a-s & & & & $\mathrm{F}_{2}$ & 73 & 1 & 2 & 0 & 0 & 0 & 0 & 0 & 0 \\
\hline PI 321637-s/Neb-T-8a-s & & & & $\mathrm{F}_{2}$ & 34 & 6 & 3 & 1 & 0 & 0 & 0 & 0 & 0 \\
\hline PI 321637-s/PI 321638-s & & & & $\mathrm{F}_{2}$ & 68 & 2 & 0 & 0 & 0 & 0 & 0 & 0 & 0 \\
\hline
\end{tabular}

${ }^{\mathrm{Z}}$ Percentage diseased area based on a 1-9 scale (CIAT, 1987), with 1, 2, 3, 4, 5, 6, 7, 8, and 9 representing (in \%) 0-11, 12-22, 23-33, 34-44, 45-55, $56-66,67-77,78-88$, and $89-100$ necrosis or chlorosis of the inoculated area $\left(4 \mathrm{~cm}^{2}\right)$, respectively.

Table 2. Segregation for resistant (1-4) and susceptible (5-9) disease severity scores ${ }^{\mathrm{z}}$ among individuals within populations derived from resistant by susceptible tepary bean crosses, that exhibited bimodal distributions in the $\mathrm{F}_{2}$ (see Table 1).

\begin{tabular}{|c|c|c|c|c|c|}
\hline $\begin{array}{l}\text { Cross or } \\
\text { generation }\end{array}$ & $\begin{array}{c}\text { Individuals } \\
\text { (no.) }\end{array}$ & $\begin{array}{c}\text { Observed } \\
1-4: 5-9\end{array}$ & $\begin{array}{c}\text { Expected } \\
1-4: 5-9\end{array}$ & $\begin{array}{c}\text { Goodness of } \\
\text { fit statistics } \\
\chi^{2}\end{array}$ & $P$ \\
\hline \multicolumn{6}{|c|}{ Neb-T-6-s $\left(\mathrm{P}_{1}\right) / \mathrm{MEX}-114\left(\mathrm{P}_{5}\right)^{\mathrm{y}}$} \\
\hline $\mathrm{F}_{1}(1-4)$ & 11 & 11:0 & All resistant & & \\
\hline $\mathrm{BC}_{1} \mathrm{P}_{1}$ & 25 & $21: 4$ & All resistant & & \\
\hline $\mathrm{BC}_{1} \mathrm{P}_{5}$ & 9 & $3: 6$ & $1: 1$ & 1.00 & $>0.20$ \\
\hline $\mathrm{F}_{2}$ & 299 & 222:77 & $3: 1$ & 0.09 & $>0.50$ \\
\hline $\mathrm{F}_{3}(1-4)$ & $149(6)^{x}$ & $148: 1$ & All resistant & & \\
\hline$(1-4)$ & 161(8) & 110:51 & $3: 1$ & 3.82 & $>0.05$ \\
\hline$(5-9)$ & $39(4)$ & $0: 39$ & All susceptible & & \\
\hline $\mathrm{F}_{3}$ families & 18 & $6: 8: 4$ & $1: 2: 1$ & 0.67 & $>0.70$ \\
\hline \multicolumn{6}{|c|}{ PI $321637-\mathrm{s}\left(\mathrm{P}_{2}\right) / \mathrm{MEX}-114\left(\mathrm{P}_{5}\right)$} \\
\hline $\mathrm{F}_{2}$ & 106 & $79: 27$ & $3: 1$ & 0.01 & $>0.90$ \\
\hline $\mathrm{F}_{3}^{2}(1-4)$ & $50(6)$ & $50: 0$ & All resistant & & \\
\hline$(1-4)$ & 143(7) & $105: 38$ & $3: 1$ & 0.19 & $>0.50$ \\
\hline (4) & $43(1)$ & $12: 31$ & $1: 3$ & 0.19 & $>0.50$ \\
\hline$(5-9)$ & $11(1)$ & $2: 9$ & $1: 3$ & 0.28 & $>0.50$ \\
\hline (5-9) & $24(1)$ & $0: 24$ & All susceptible & & \\
\hline $\mathrm{F}_{3}$ families & 16 & $6: 7: 2: 1$ & $1: 2: 1^{\mathrm{w}}$ & 1.03 & $>0.50$ \\
\hline \multicolumn{6}{|c|}{ Neb-T-8a-s $\left(\mathrm{P}_{3}\right) / \mathrm{MEX}-114\left(\mathrm{P}_{5}\right)$} \\
\hline $\mathrm{F}_{1}$ & 7 & $7: 0$ & All resistant & & \\
\hline $\mathrm{BC}_{1} \mathrm{P}_{3}$ & 38 & $37: 1$ & All resistant & & \\
\hline $\mathrm{BC}_{1} \mathrm{P}_{5}$ & 40 & $6: 34$ & $1: 3$ & 2.13 & $>0.10$ \\
\hline $\mathrm{F}_{2}$ & 163 & $100: 63$ & 9:7 & 1.50 & $>0.20$ \\
\hline $\mathrm{F}_{3}(1-4)$ & $136(7)$ & 136:0 & All resistant & & \\
\hline$(1-4)$ & $186(11)$ & $148: 38$ & $3: 1$ & 2.02 & $>0.10$ \\
\hline$(1-4)$ & $120(7)$ & $74: 46$ & $9: 7$ & 1.42 & $>0.20$ \\
\hline$(5-9)$ & $147(4)$ & $0: 147$ & All susceptible & & \\
\hline $\mathrm{F}_{3}$ families & 29 & $7: 11: 7: 4$ & $1: 4: 4: 7$ & 22.78 & $<0.01$ \\
\hline
\end{tabular}

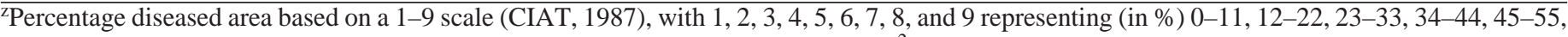
$56-66,67-77,78-88$, and $89-100$ necrosis or chlorosis of the inoculated area $\left(4 \mathrm{~cm}^{2}\right)$, respectively.

'The resistant $\left(\mathrm{P}_{1,2,3}\right)$ and suceptible $\left(\mathrm{P}_{5}\right)$ parents of each cross averaged 1 and 9 for disease score, respectively.

${ }^{x}$ Number of combined progenies in parentheses. Only progenies exhibiting homogeneous segregation patterns as indicated by heterogeneity interaction $\chi^{2}$ tests (not shown) of $P>0.05$ were combined.

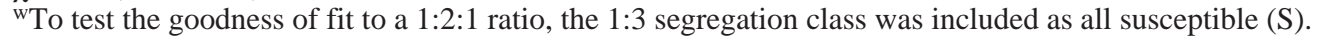


ambient conditions in the greenhouses and screenhouses at the USDA-ARS, Tropical Agriculture Research Station, in Mayagüez, PR. The natural photoperiod ranged from 11 (December) to 13 (June) $h$. The average day and night temperatures ranged from 26 (December) to $35^{\circ} \mathrm{C}$ (June) and 17 (December) to $23{ }^{\circ} \mathrm{C}$ (June), respectively. Four to five plants were grown per $23-\mathrm{cm}$-diameter pot containing an artificial soil medium (Sunshine Mix No. 1, Fision, Hort., Vancouver, B.C.). Pots were watered and fertilized as needed to promote healthy plants. Inoculations were conducted from January 1994 to December 1995. The central leaflet of the first trifoliolate leaf was inoculated, with a suspension of strain $X c p$ $484 \mathrm{a}$ that had been diluted with sterile $0.01 \mathrm{~m}$ phosphate buffer to 3 to $6 \times 10^{7} \mathrm{CFU} / \mathrm{mL}, \approx 14 \mathrm{~d}$ after planting by the multiple-needle method (Andrus, 1948; Zapata et al., 1985). Control plants were inoculated with just buffer.

Disease reactions were evaluated $14 \mathrm{~d}$ after inoculation by scoring the percentage of diseased area based on a 1-9 scale [Centro Internacional Agricultura Tropical (CIAT), 1987], with 1, $2,3,4,5,6,7,8$, and 9 representing (in \% ) 0-11, 12-22, 23-33, 34$44,45-55,56-66,67-77,78-88$, and 89-100 necrosis or chlorosis of the inoculated area $\left(4 \mathrm{~cm}^{2}\right)$, respectively. In this study, bimodal distributions in the $F_{2}$ generation generally indicated that plants scoring from 1-4 were resistant and from 5-9 susceptible (Table 1). This demarcation between resistance and susceptibility was supported by $\mathrm{F}_{3}$ progenies derived from $\mathrm{F}_{2}$ plants scoring 1-4, either segregating for resistance or having uniformly resistant reactions; whereas, plants with scores from 5-9 always had uniformly susceptible progenies (Table 2). Of each $\mathrm{F}_{2}$ population 75 to 200 plants were inoculated. About 20 individual plants within $\mathrm{F}_{3}$ progenies derived from 16 to 34 randomly selected $F_{2}$ plants were subsequently inoculated.

For $\mathrm{F}_{2}$ populations exhibiting bimodal distributions for disease reaction (Table 1), the $\mathrm{F}_{1}, \mathrm{~F}_{2}, \mathrm{BC}_{1} \mathrm{P}_{1,2,3}$ and $\mathrm{BC}_{1} \mathrm{P}_{5}$, and $\mathrm{F}_{3}$ generations were analyzed by chi-square $\left(\chi^{2}\right)$ tests to compare significance of fit between theoretical and observed Mendelian segregation ratios for resistant and susceptible plants. Generation means analysis, involving the $\mathrm{P}_{4}$ and $\mathrm{P}_{5}$ parents, $\mathrm{F}_{1}, \mathrm{~F}_{2}, \mathrm{BC}_{1} \mathrm{P}_{4}$, and $\mathrm{BC}_{1} \mathrm{P}_{5}$ generations, was conducted for the PI 321638-s/MEX-114 cross which exhibited a continuous $\mathrm{F}_{2}$ distribution for disease reaction (Table 1). A simple additive-dominance model ( $\mathrm{Ng}, 1990)$ based on mean disease severity scores for the respective generations was used to examine the inheritance of common bacterial blight resistance in this cross.

\section{Results and Discussion}

The $\mathrm{F}_{2}$ populations from crosses involving Neb-T-6-s and PI 321637-s by the susceptible tepary MEX-114 exhibited 3:1 segregation ratios for numbers of resistant to susceptible plants, suggesting the hypothesis that resistance in these lines was conditioned by a single dominant gene (Tables 1 and 2). A 1:1 ratio for segregation in the $\mathrm{BC}_{1} \mathrm{P}_{5}$, all resistant $\mathrm{F}_{1}$ plants, and a 1:2:1 segregation for all resistant, segregating 3:1 for resistant and susceptible, and all susceptible individuals among $\mathrm{F}_{3}$ progenies supported dominant monogenic resistance in Neb-T-6-s. A few susceptible individuals occurred within otherwise all resistant $\mathrm{F}_{3}$ and $\mathrm{BC}_{1} \mathrm{P}_{1}$ progenies. Perhaps these individuals were resistant but succumbed to an excessive amount of bacterial suspension inserted via the multiple-needle inoculation procedure. Some inoculations, performed during the summer months under higher temperatures ideal for severe Xcp infection (Saettler, 1989), may also have contributed to the resistance of a few individuals being overcome. The few susceptible $\mathrm{BC}_{1} \mathrm{P}_{1}$ individuals could have resulted from self-pollination. Modifier genes having a minor effect on expression of resistance could also have caused a few outlier reactions to occur in otherwise homozygous progenies.

For PI 321637-s some $\mathrm{F}_{3}$ progenies from previously resistant or susceptible plants in the previous generation segregated 1:3 for resistance, indicating a minor-effect gene with recessive inheritance also conditioned resistance in this line. Interestingly, only progenies from resistant individuals scoring a 4 in the PI 321637 s/MEX-114 population segregated 1:3. For all other populations, progenies from plants previously scoring 4 were completely resistant or had segregation ratios in favor of resistance and progenies from plants previously scoring 5 or above were all susceptible, indicating that our classification of disease severity scores from 14 as resistant and 5-9 as susceptible was appropriate. Similar dominant monogenic resistance to Xcp 484a was observed for two additional tepary bean lines GN-605-s and PI 440806-s (data not shown; Urrea, 1996).

A digenic 9:7 segregation pattern for numbers of resistant to susceptible individuals in the $\mathrm{F}_{2}$ generation suggested the presence of two complementary dominant genes conditioned resistance in Neb-T-8a-s (Tables 1 and 2). Combined 1:3 segregation in the $\mathrm{BC}_{1} \mathrm{P}_{5}$ generation, all resistant plants in the $\mathrm{F}_{1}$ generation, and individuals within $\mathrm{F}_{3}$ progenies either all resistant, segregating 3:1 or 9:7 for resistance and susceptibility, or all susceptible, supported the hypothesis for inheritance conditioned by two dominant genes with complementary effects. The $\mathrm{F}_{3}$ generation did not fit the expected 1:4:4:7 segregation for progenies with all resistant, 3:1, $9: 7$, or all susceptible individuals. The inoculated $F_{2}$ plants set aside for generation of $\mathrm{F}_{3}$ progenies, that were susceptible, were less likely to produce enough $\mathrm{F}_{3}$ seed for testing; thus, probably contributed to the observed $\mathrm{F}_{3}$ segregation skewed toward all resistant progenies. A similar 9:7 ratio was observed by Scott and Michaels (1988) for tepary-derived resistance in $F_{2}$ populations of common bean.

Significant additive epistatic effects and estimated presence of three resistance genes by the generation means analysis (Table 3) corroborated the quantitative inheritance suggested by the continuous $\mathrm{F}_{2}$ distribution (Table 1) for disease reaction in the PI 321638-s/MEX-114 cross. High heritability and $F_{2}$ segregation

Table 3. Adequacy of the additive/dominance model, broad sense heritability (h), estimated number of genes conditioning resistance (k), and genetic effects $^{\mathrm{z}}(\mathrm{ISE}): \mathrm{d}=$ additive effects and $\mathrm{i}=$ epistasis between additive effects, obtained from generation means analyses of common bacterial blight reaction $^{\mathrm{y}}$ to $X c p$ strain $484 \mathrm{a}$ in a resistant $\mathrm{X}$ susceptible tepary bean cross that exhibited a continuous $\mathrm{F}_{2}$ distribution (Table 1).

\begin{tabular}{lcccc}
\hline \hline & Model & & & \\
Cross & $(3 \mathrm{df})$ & $\mathrm{h}$ & $\mathrm{k}$ & $\mathrm{d}$ \\
\hline PI 321638-s/MEX-114 & $72.0^{* *}$ & 0.96 & 3.16 & $-219.2(0.02)^{* * *}$ \\
\hline
\end{tabular}

${ }^{\mathrm{z}}$ All dominance effects, epistasis between dominance effects, and epistasis between additive and dominance effects within this model were nonsignicant.

yPercentage diseased area based on a 1-9 scale (CIAT, 1987), with 1, 2, 3, 4, 5, 6, 7, 8, and 9 representing (in \%) 0-11, 12-22, 23-33, 34-44, 45-55, $56-66,67-77,78-88$, and $89-100$ necrosis or chlorosis of the inoculated area $\left(4 \mathrm{~cm}^{2}\right)$, respectively.

*,** Significant at $P=0.05$ or 0.01 , respectively. 
skewed toward resistance suggested that environment had a minimal affect on expression of this quantitative resistance. An $F_{2}$ segregation of 168 resistant (disease scores from 1-4) to 19 susceptible (disease scores from 5-9) individuals, combined with $3: 1,13: 3$, and 55:9 resistant to susceptible segregation ratios observed in some $\mathrm{F}_{3}$ progenies (data not shown), suggests that the quantitative resistance in PI 321638-s may be conditioned by one dominant and two recessive genes. This speculative trigenic inheritance for resistance to common bacterial blight parallels the inheritance described by McElroy (1985) and Scott (1988) where resistance was conditioned by one major and two minor or modifying genes. Urrea (1996) also observed quantitative inheritance, involving from two to five resistance genes, in the tepary lines Neb-T-1s, GN-610-s, PI 440788-s, and PI 502217-s.

No segregation for susceptibility was observed in any of the $\mathrm{F}_{2}$ populations derived from crosses between resistant tepary bean lines (Table 1), indicating that at least one resistance gene was probably in common across Neb-T-6-s, Neb-T-8a-s, PI 321637-s and PI 321638-s. A similar limited variability for resistance to rust was observed in cultivated tepary bean by Miklas and Stavely (1998), providing further support for the occurrence of a bottleneck effect during domestication of this species. Conversely, the mono-, di-, and trigenic inheritance observed here and elsewhere (Drijfhout and Blok, 1987; McElroy, 1995; Scott and Michaels, 1992) suggests that the variability for resistance to common bacterial blight in cultivated tepary bean has probably not been fully exploited in the improvement of common bean.

\section{Literature Cited}

Andrus, C.F. 1948. A method of testing beans for resistance to bacterial blight. Phytopathology 38:757-760.

Bai, Y., T.E. Michaels, and K.P. Smith. 1997. Identification of RAPD markers linked to common bacterial blight resistance genes in Phaseolus vulgaris L. Genome 40:544-551.

Cafati, C.R. and H. Kimati. 1972. Reaccion de variedades de frejol a Xanthomonas phaseoli y Xanthomonas phaseoli var. fuscans. Agr. Tecnica 32:153-160.

Centro Internacional Agricultura Tropical. 1987. Standard system for the evaluation of bean germplasm. CIAT, Cali, Colombia.

Drijfhout, E. and W.J. Blok. 1987. Inheritance of resistance to Xanthomonas campestris pv. phaseoli in tepary bean (Phaseolus acutifolius). Euphytica 36:803-808.

Dursun, A., D.P. Coyne, M.F. Mohamed, and G. Jung. 1995. Inheritance of resistance to common bacterial blight in tepary beans. Annu. Rpt. Bean Improv. Coop. 38:162-163.

Freytag, G.F. 1989. Inheritance of resistance to three strains of common bacterial blight (Xanthomonas campestris) in the cultivated tepary bean (Phaseolus acutifolius var. latifolius). Annu. Rpt. Bean Improv. Coop. 32:101-102.

Honma, S. 1956. A bean interspecific hybrid. J. Hered. 47:217-220.
Jung, G., P.W. Skroch, D.P. Coyne, J. Nienhuis, E. Arnaud-Santana, H.M. Ariyarathne, S.M. Kaeppler, and M.J. Bassett. 1997. Molecular-markerbased genetic analysis of tepary bean-derived common bacterial blight resistance in different developmental stages of common bean. J. Amer. Soc. Hort. Sci. 122:329-337.

McElroy, J.B. 1985. Breeding dry beans, Phaseolus vulgaris L., for common bacterial blight resistance derived from Phaseolus acutifolius A. Gray. PhD thesis. Cornell Univ., Ithaca, N.Y.

Mejía-Jiménez, A., C Munoz, H.J. Jacobsen, W.M. Roca, and S.P. Singh. 1994. Interspecific hybridization between common and tepary beans: Increased embryo growth, and efficiency of hybridization through recurrent and congruity backcrossing. Theor. Appl. Genet. 88:324-331.

Michaels, T.E. 1992. Genetic control of common blight resistance in lines derived from P. vulgaris/P. acutifolius crosses. Annu. Rpt. Bean Improv. Coop. 35:40-41.

Miklas, P.N., E. Johnson, V. Stone, J.S. Beaver, C. Montoya, and M. Zapata. 1996. Selective mapping of QTL conditioning disease resistance in common bean. Crop Sci. 36:1344-1351.

Miklas, P.N., J.C. Rosas, J.S. Beaver, L. Telek, and G.F. Freytag. 1994. Field performance of select tepary bean germplasm in the tropics. Crop Sci. 34:1639-1644.

Miklas, P.N. and J.R. Stavely. 1998. Incomplete dominance of rust resistance in tepary bean. HortScience 33:143-145.

$\mathrm{Ng}, \mathrm{T} . J .1990$. Generation means analysis by microcomputer. HortScience 25:363.

Nodari, R.O., S.M. Tsai, P. Guzmán, R.L. Gilbertson, and P. Gepts. 1993. Toward an integrated linkage map of common bean. III. Mapping genetic factors controlling host-bacteria interactions. Genetics 134:341350.

Park, S.O., D.P. Coyne, A. Dursen, and G. Jung. 1998. Identifying randomly amplified polymorphic DNA (RAPD) markers linked to major genes for common bacterial blight resistance in tepary bean. J. Amer. Soc. Hort. Sci. 122:329-337.

Pratt, R.C. and S.G. Gordon. 1994. Introgression of Phaseolus acutifolius A. Gray genes into the Phaseolus vulgaris L. genome. Plant Breeding 113:137-149.

Saettler, A.W. 1989. Common bacterial blight. In: H.F. Schwartz and M. Pastor-Corrales (eds.) Bean production problems in the tropics. 2nd ed. CIAT, Cali, Colombia.

Scott, M.E. 1988. Interspecific Phaseolus cross progeny: Incompatibility mechanism and reaction to common bacterial blight. MS thesis, Univ. of Guelph, Ontario, Canada.

Scott, M.E. and T.E. Michaels. 1988. Inheritance of resitance to common bacterial blight in common bean. Annu. Rpt. Bean Improv. Coop. 31:72.

Scott, M.E. and T.E. Michaels. 1992. Xanthomonas resistance of Phaseolus interspecific cross selection confirmed by field performance. HortScience 27:348-350.

Urrea, C.A. 1996. Genetics of resistance to common bacterial blight in tepary bean (Phaseolus acutifolius) and identification of RAPD markers linked to genes that confer resistance. MS thesis, Univ. of Puerto RicoMayagüez.

Zapata, M., G.F. Freytag, and R.E. Wilkinson. 1985. Evaluation for bacterial blight resistance in beans. Phytopathology 75:345-35 